Irena Planinić, dipl. oec.

JP „Elektroprivreda HZ-HB“ d.d. - Mostar, BiH

irena.planinic@ephzhb.ba

\title{
TRŽIŠTE KAPITALA BOSNE I HERCEGOVINE DESETLJEĆE NAKON GLOBALNE FINANCIJSKE KRIZE
}

Primljeno: 26. kolovoza 2019.

Prihvaćeno: 15. prosinca 2019.

Stručni rad

\section{Sažetak}

Između gospodarskog razvoja i financijskog tržišta postoji jaka korelacija. Gospodarski razvoj potiče rast štednje a samim time i razvoj financijskog tržišta. Pokazatelj razvijenosti financijskog tržišta jeste tržišna kapitalizacija mjerena $\%$ nominalnog BDP-a. U radu se analizira razvijenost tržište kapitala Bosne $i$ Hercegovine sa tranzicijskim zemljama Srednjoistočne Europe. Primjenom metoda analize, metode deskripcije, kvantitativne $i$ komparativne metode nastoji se utvrditi da je tržište kapitala Bosne i Hercegovine, visoko rizično nedovoljno razvijeno i siromašno. Uspoređujući ga sa odabranim tranzicijskim zemljama Srednjoistočne Europe, od 2008 do 2018. godine, pokušati utvrditi ima li velikih odstupanja u razvijenosti tržišta kapitala.

Ključne riječi: financijsko tržište, tržište kapitala;

JEL: E44 


\section{FINANCIJSKA TRŽIŠTA U UVJETIMA SVJETSKE FINANCIJSKE KRIZE}

Financijska tržišta predstavljaju prijenosni mehanizam između osoba koji imaju višak sredstava i onih kojima su ta sredstva potrebna. Ona su krvotok globalne ekonomije, gdje se promjene na tržištu jedne države odražavaju pozitivno ili negativno na tržištu druge države. To se najbolje može vidjeti na primjeru SAD - a, najrazvijenijem tržištu, gdje se nastanak financijske krize odrazio na ostale zemlje. Budući da je to središte mreže koje povezuju financijske sustave gotovo svih zemalja, kriza se vrlo brzo proširila. Svjetska ekonomska kriza dovela je do pada cijena dionica najvećih tvrtki koje su sa svim ekonomskim parametrima bile daleko od krize, ali zbog masovne panike stanovništva i straha investitora nisu se mogle oduprijeti. Ekonomska kriza imala je jak utjecaj na sve zemlje svijeta. Neslaganja u bankarskom sektoru dovela su do pada cijena dionica, stečajeva, povrata imovine i velike stope nezaposlenosti.

Svjetskoj krizi prethodilo je povećanje osnovnih životnih namirnica u 2007. godini i u polovini 2008. godine, dok su cijene plaća zaposlenika ostale iste. Zbog različitih struktura gospodarstva i potrošnje, veliko povećane cijena nafte i potrošnje, utjecalo je na povećanje siromaštva. ${ }^{1}$ Posljedice financijske krize su gubitak štednje, mirovina, posla, dovodi do odustajanja ulaganja u veće investicijske projekte, a svakodnevna potrošnja svodi se na minimum.

Analitičari financijskog tržišta i globalne krize donose zaključke koji su u skladu s Minskyjevim modelom financijske krize. Njegov model naglašava da neregulirana tržišta nisu dinamički stabilni sustavi koji se približavaju ravnoteži punog zapošljavanja, ali u sustavima koje su cikličke prirode, krize nisu neobičan događaj. Bitan element ovog cikličnog sustava je endogena priroda percepcije i očekivanja rizika. ${ }^{2}$ Minskyn navodi sljedeće: u uvjetima mirne ekspanzije, financijske institucije koje traže profit izmišljaju nove oblike novca, zamjenjujući novac u portfeljima za različite vrste aktivnosti. S razvojem financijskih inovacija i dodatnim optimizmom stvara se dodatna potražnja za dobrima i uslugama, te prilika za investiranje. Sve ovo predstavlja uzlaznu fazu u kojoj novi financijski instrumenti i sklonost riziku čine sustav osjetljivim. U određenom trenutku neki događaj investitore dovodi do visokog stupnja izloženosti rizika i počinje faza financijskih poteškoća. Pojava svijesti o većem riziku dovodi do prebacivanje portfelja investitora u korist sigurnijih i likvidnijih sredstava. Višak potražnje za

1 Juričić, Lj. (2010) „Financijska kriza i financijska politika“ portal hrvatskih znanstvenih i stručnih časopisa, Ekonomski pregled, Zagreb, Vol. 61, No. 5-6, 2010 str. 318.

2 Frenkel, R., Rapetti, M. (2009) „A developing country view of the current global crisis: what should not be forgotten and what should be done", Cambridge Journal of Economics, 2009., str. 687.

https://academic.oup.com/cje/article/33/4/685/1733939?searchresult=1 (pristup 25.06.2019.) 
likvidnošću i niskorizičnim ulaganjima završavaju probijanjem tzv. balona koji dovodi do masivnog gubitka bogatstva. Deflatorna kretanja financijskih tržišta čine većinu investitora ograničenim likvidnošću ili bankrotiranjem što u oba slučaja negativno utječe na odluke o potrošnji. Ono što je počelo kao kontrakcija financijskog sektora sada se proširilo na cjelokupno gospodarstvo.

Nakon nastanka svjetske ekonomske krize javili su se brojni kritičari zapadnog koncepta društva koji je na njemu zasnovan. Država je bila prinuđena spašavati velike privatne tvrtke, dionička društva, od propasti, kako se njihov bankrot ne bi lančano proširilo na cjelokupnu ekonomiju. Ova intervencija ne znači da je država dobro upravlja gospodarstvom, a pogotovo ne da sanira gubitke tvrtki koje će na kraju plaćat porezni obveznici, već je ona privremena mjera. Problem je što nitko od kritičara nije ponudio rješenje i model budućeg društva koje će biti organizirano na nekim drugim pravilima. ${ }^{3}$

Globalizacija financijskih tržišta sa brzim tempom financijskih inovacija uzrokovana čestim državnim spašavanjem doveli su do svjetske financijske krize. Ozbiljnost svjetske financijske krize jasno daje smjernice da je putanja rasta financijskih tržišta posljednjih godina neodrživa i da se mora preokrenuti. Nije moguće da vrijednost financijske imovine ostane tako velika u odnosu na realnu ekonomiju jer realno gospodarstvo ne može dosljedno generirati novčane tokove potrebne za održavanje „,napuhanih“ financijskih potraživanja.

Kada je riječ o Bosni i Hercegovini u uvjetima svjetske gospodarske krize stabilnost se održavala sljedećim čimbenicima: ${ }^{4}$

1. Valutni odbor uveden 1997. godine Daytonskim mirovnim sporazumom. Valutni odbor pridonio je stabilnosti tečaja i povjerenje u domaću valutu (konvertibilne marke) ali je zato onemogućio centralnoj banci vođenje slobodne monetarne politike. Centralna banka u uvjetima valutnog odbora nema mogućnost davanja kredita državi i poslovnim bankama. Bankarski sektor BiH posluje pod strogim zakonskim regulativama, i zahvaljujući tome vlasnici depozita nisu podizali svoja sredstva u prvim znacima krize.

2. Platna bilanca Bosne i Hercegovine koja je od samih početaka ne pokazuje pozitivan rezultat. Veći dio priliva odnosio se na devizna sredstva iseljenika. Deficit u trgovinskoj bilanci ublažavao se kapitalnim transferima iz inozemstva javnom sektoru te pokojom stranom investicijom.

3 Jeremić,Z. „Finansijska tržišta i finansijski posrednici“, Univerzitet Singidunum, Beograd, 2012. str. 16

4 Grgić D., Kordić G. (2011) „Analogija krize zemlja s margine eurozone s krizom u Bosni $i$ Hercegovini i Hrvatskoj “ Ekonomska misao i praksa, Sveučilište u Dubroniku, No. 1, 2011, str. 212.-214. 
3. U gospodarstvu Bosne i Hercegovine većinskim dijelom prevladava javni sektor. Budući da on ne pridonosi trgovini robama i uslugama, gospodarski rast na temelju inozemne razmjene je gotovo nemoguć. Prikupljeni proračunski prihodi usmjeravaju se na administrativne troškove i socijalne transfere.

\section{KRETANJE NA TRŽIŠTIMA KAPITALA ZEMALJA SREDNJOISTOČNE EUROPE (CEE)}

Trgovanje na tržištima kapitala se odvija na primarnom ili sekundarnom tržištu. Primarno tržište je ono na koje se uvode nove dionice i obveznice. Investicijske fondovi, korporacije i ulagači pojedini mogu kupovati vrijednosnice na primarnom tržištu. Tržišta kapitala imaju dobro razvijena sekundarna tržišta, gdje se odvija prodaja prethodno izdanih vrijednosnica. ${ }^{5}$ Svrha tržišta kapitala jeste usmjeravanje slobodnih kapitalnih projekata u projekte realnog sektora koji bi potakli gospodarski rast. Kada se govori o sekundarnom tržištu kapitala razvijenih zemalja ono odražava cjelokupni razvoj tržišta kapitala, a isto se ne može reći za tranzicijske zemlje. Naime, tržišta kapitala tranzicijskih zemalja su se razvila preko noći kroz proces privatizacije, dok se u razvijenim zemljama primarno i sekundarno tržište razvijalo istodobno dugi niz godina.

Radi brojnih prepreka i neiskorištenih kapaciteta tržišta kapitala CEE zaostaju za razvijenim zapadnoeuropskim tržištima. Neiskorištenosti kapaciteta ogleda se u oskudnoj ponudi na tržištu dioničkih odnosno dužničkih vrijednosnih papira, nisku potražnju malih ulagača te administrativna opterećenja koja guše male ulagače. Kao jedan od problema nerazvijenosti tržišta jeste i nepovjerenje ulagača u lokalna financijska tržišta. Razvoj financijskih tržišta gospodarstva usko je povezan s njegovim cjelokupnim razvojem. Dobro funkcionirajući financijski sustavi pružaju dobre i lako dostupne informacije koje mogu smanjiti transakcijske troškove i kasnije poboljšati raspodjelu resursa i potaknuti gospodarski rast. Bankarki sustavi i tržišta dionica potiču rast, i glavni su čimbenici za smanjenje siromaštva. Otvorene ekonomije sa zdravom makroekonomskom politikom, dobrim pravnim sustavima i zaštitom dioničara privlače kapital stoga imaju veća financijska tržišta.

Nakon krize tržište kapitala Srednjoistočne Europe se sporo oporavlja, a to je dovelo do stagnacije tržišta dionica i obveznica.

Mishkin S. F., Easkin, G. S., (2005) „,Financijska tržišta+ institucije“, Mate, Zagreb, str. 242. 
Grafikon 1: Prikaz prometa dionica tržišta CEE (u \% BDP-u)

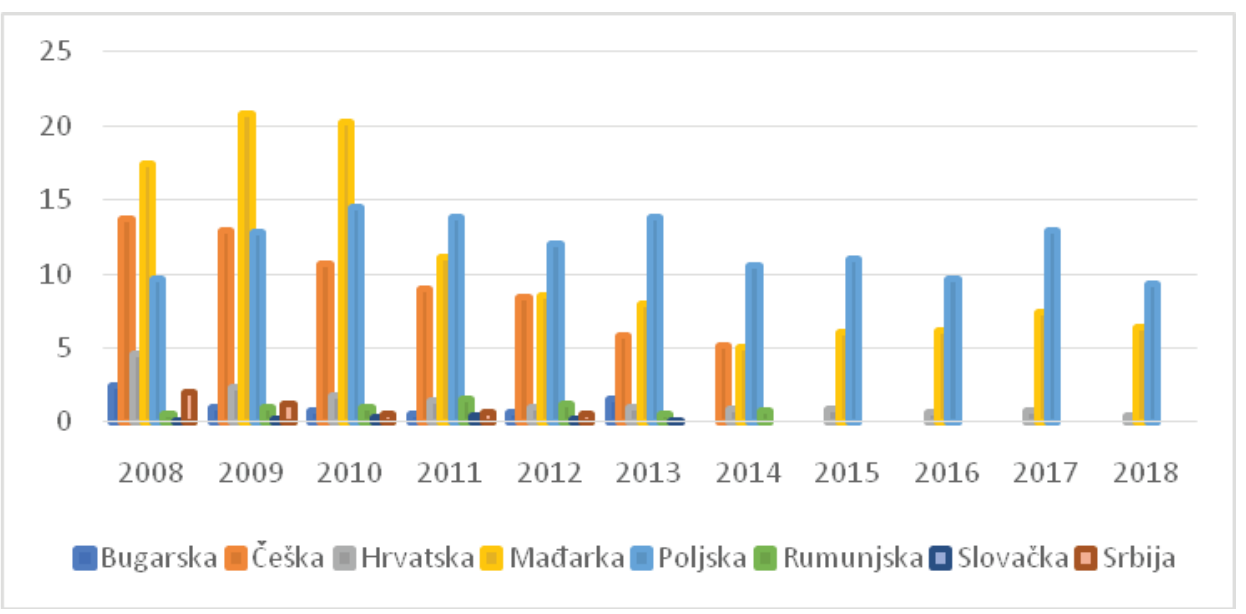

Izvor: izrada autora prema podatcima preuzetih sa izvor: https://data.worldbank.org/indicator/CM.MKT.TRAD.GD.ZS (16.07.2019)

Grafikon 2: Prikaz prometa obveznica tržišta CEE u \% BDP

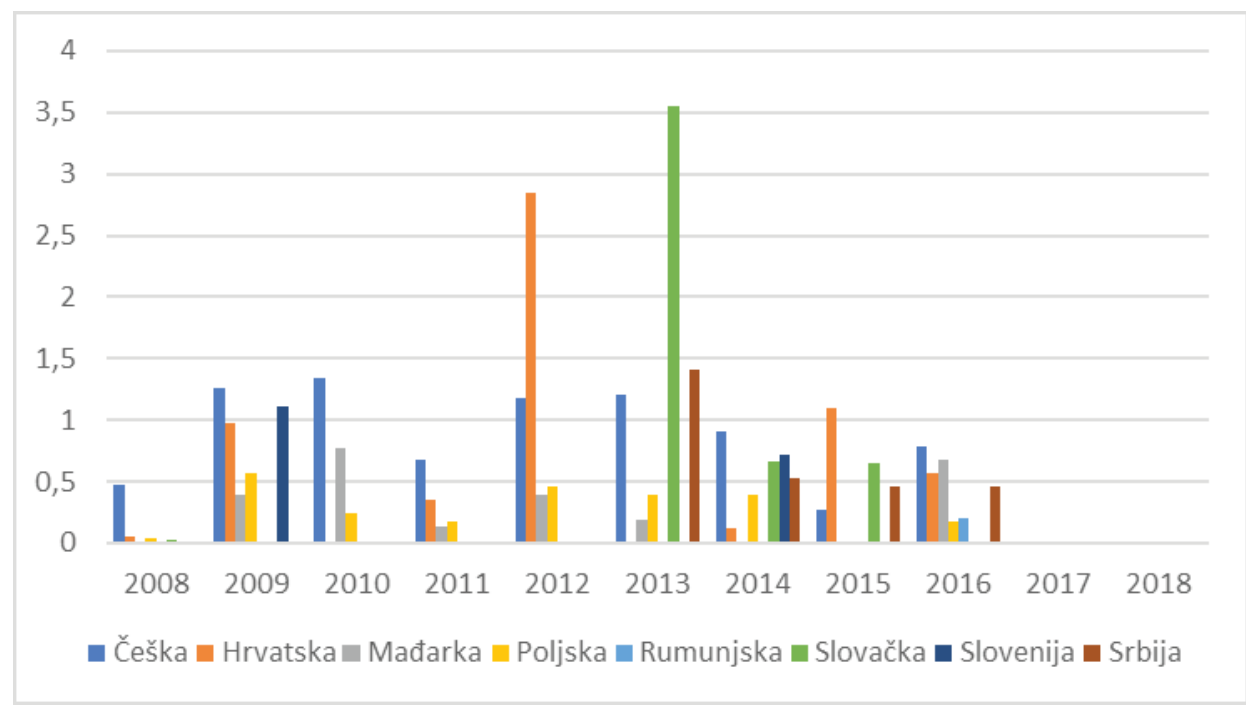

Izvor: izrada autora po podatcima preuzetih sa: https://data.worldbank.org/indicator/ CM.MKT.TRAD.GD.ZS (16.07.2019)

Za stabilnost tržišta kapitala kao i njegov razvoj potreban je realan gospodarski rast, što znači da razvoj tržišta kapitala dovodi do ekonomskog razvoja zemlje. Tržišta kapitala srednjoistočne Europe predstavljaju slabije makroekonomske 
fundamente koja su proteklih deset godina iznimno plitka, slabije likvidna te malih obima trgovanja. U usporedbi sa razvijenim tržištima, mogu se okarakterizirati kao slabo razvijena i nisu od velikog značaja u smislu pribavljanja kapitala za investicijske projekte ili neke značajne uloge razvoja financijskog sustava.

Postavlja se pitanje može li se financijska kriza izbjeći te ako ne može kako je lakše prebroditi? Financijska kriza nastaje kao posljedica brzog razvoja i visokog rasta. Promjena novih tehnologija mijenja logiku tržišta, ili kriza može proizaći iz financijske nestabilnosti, trgovinskih ratova i sukoba. Kriza se ne može izbjeći ali se može smanjiti njena veličina i posljedice. Kao jedan od primjera ublaživanja krize svakako jeste unija tržišta kapitala. Unija tržišta kapitala predstavlja sigurno ulaganje investitoru na stabilnim financijskim tržištima. Što je kapital veći za ulaganje izvan bankarskog sektora, to je manja izloženost bankarskog sektora riziku gospodarstva. Ono što je potrebno jeste poticati privatno vlasništvo, privatni kapital, različite oblike rizičnog kapitala i privatnu štednju.

\section{TRŽIŠTA KAPITALA U BOSNI I HERCEGOVINI}

Govoreći o regulaciji i organizaciju tržišta kapitala u BiH ono je složeno i organizirano na više razina. Kada je riječ o entitetskim razinama tržište kapitala podijeljeno je na dva samostalna i neovisna tržišta ${ }^{6}$ (Sarajevska burza SASE i Banjalučka burza). U Republici Hrvatskoj također su djelovale dvije bure (Zagrebačka i Varaždinska) koje su 21.12.2006. godine potpisale ugovor o pripajanju, da bi 16.03.2007. godine u RH trgovina vrijednosnim papirima postala centralizirana, pri čemu je završen proces konsolidacije tržišta kapitala RH. Očekivanja da se to primjeni i na $\mathrm{BiH}$ do sada se nisu ispunila. Zakonsku osnovu za razvoj tržišta kapitala BiH čine ${ }^{7}$ : Zakon o vrijednosnim papirima, Zakon o Komisiji za vrijednosne papire, Zakon o društvima za upravljanje investicijskim fondovima i investicijskim fondovima, Zakon o Registru vrijednosnih papira i Zakon o gospodarskim društvima.

Tržište kapitala u BiH karakteristično je za siromašne i nerazvijene zemlje, a razvoj samog tržišta je usporen zbog nekvalitetnih investicija i nepovoljne strukture. Investiranje u BiH većinom ovisi o stranoj štednji. Prema studiji koju je uradila EBRD, uz preporuke OECD -a, utvrđena je procjena zakonske uređenosti financijskog tržišta $\mathrm{BiH}$. Analiza je pokazala da se najviše postiglo u, sprečavanju pranja novca, razvijenosti posrednika, kolektivnoj shemi i zaštiti informacija. Najnerazvijeniji segment predstavlja brojnost instrumenata sa kojima se trguje na organiziranom tržištu kapitala. ${ }^{8} \mathrm{Na}$ grafikonu 3 dan je prikazan prometa na $\mathrm{BiH}$ burzama kroz promatrani period od 2009. do 2018. godine.

\footnotetext{
https://www.cbbh.ba/press/edukacija/673?lang=hr (31.07.2019.)

7 Gadžić, M. (2013) „Financijska tržišta i institucije“, Sveučilište u Mostaru, Mostar, str. 237.

8 Kumalić, I. (2013) „, Razvijenost financijskog tržišta u Bosni i Hercegovini“ Časopis za ekonomiju i tržišne komunikacije, Fakultet poslovne ekonomije, Banja Luka, str. 68.
} 
Grafikon 3: Prikaz ukupnog prometa SASE i BLSE od 2009. - 2018.

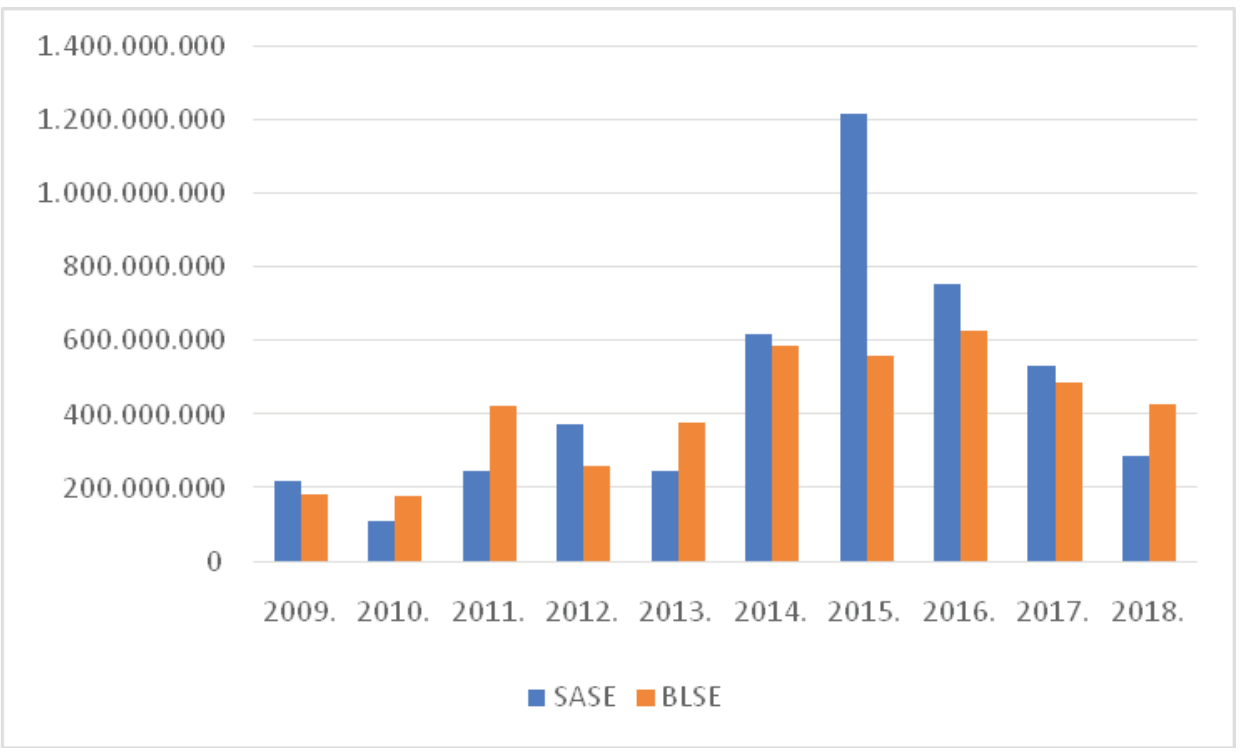

Izvor: vlastita izrada autora koristeći podatke sa: https://blberza.com/Pages/periodicalstatreports.aspx (31.07.2019)

http://www.sase.ba/v1/Izvje\%C5\%A1taji/Ostali-izvje\%C5\%A1taji/Godi\%C5\%A1nji-izvje\%C5\%A1taji (31.07.2019.)

Tijekom razdoblja 2009. - 2019. godine na burzama je ostvaren ukupan promet od 8.711.129.499 KM, od toga 4.605.777.726 KM na Sarajevskoj burzi (SASE) što čini 52,87 \% ukupnog prometa ostvarenog na BH burzama, a iznos 4.105.351.773 KM (47,13\%) čini ostvaren promet na Banjalučkoj burzi. Na grafikonu je vidljivo da od 2013. godine Sarajevska burza ima lagani pad u ostvarivanju ukupnog prometa, nakon čega ostvareni promet raste, da bi u 2015. godini dostigla vrhunac u iznosu od 1.219.583.581,00 KM. Kada je riječ o Banjalučkoj burzi nema naglih oscilacija u ostvarenom prometu tijekom promatranog perioda.

Važan pokazatelj razvijenosti BiH financijskog tržišta svakako je tržišna kapitalizacija. Ona predstavlja cijene dionica, umanjen za broj izdanih dionica za kotirana domaća poduzeća. Investicijski fondovi i tvrtke čiji je jedini poslovni ili posjedovanje dionica drugih društava koja ne kotiraju na tržištu ne ubrajaju se u tržišnu kapitalizaciju. U tabeli ispod vidljivo je da je tržišna kapitalizacija $\mathrm{BiH}$ iznosila 23\% nominalnog BDP-a u prosinu 2018. godine, što predstavlja pad od 3\% u odnosu na prosinac 2017. godine (tržišna kapitalizacija 25\%). Najveći postotak zabilježen je u prosinu 2008. godine gdje je tržišna kapitalizacija iznosila 44\% nominalnog BDP-a. Analizirajući period unatrag deset godina do danas vidljivo je da je stanje na tržištu kapitala nepovoljno, slabo i nerazvijeno. Tržište 
kapitala nema veliku ulogu u financiranju poduzeća, pod utjecajem je ostvarivanja državnih ciljeva, te ima mali broj internih dioničara.

Tablica 1: Usporedba tržišna kapitalizacija BiH sa tržištima odabranih zemalja izražena u $\%$ BDP - a

\begin{tabular}{|c|c|c|c|c|c|c|c|c|c|c|c|}
\hline NAZIV ZEMLJE & 2008 & 2009 & 2010 & 2011 & 2012 & 2013 & 2014 & 2015 & 2016 & 2017 & 2018 \\
\hline Bugarska & 17,127 & 16,161 & 14,383 & 15,399 & 11,980 & 12,167 & 11,648 & 9,695 & 10,286 & 23,377 & 24,800 \\
\hline $\begin{array}{c}\text { Bosna i } \\
\text { Hercegovina }\end{array}$ & 44,129 & 43,127 & 42,081 & 30,176 & 30,267 & 30,718 & 30,760 & 31,468 & 27,517 & 24,971 & 23,034 \\
\hline Češka & 27,130 & 32,910 & 35,029 & 26,297 & 28,131 & 26,683 & 24,115 & 23,945 & 21,906 & 24,817 & 399,005 \\
\hline Hrvatska & 40,852 & 40,851 & 42,793 & 39,175 & 38,629 & 35,861 & 38,066 & 37,730 & 40,754 & 37,812 & 34,769 \\
\hline Madarska & 12,400 & 22,397 & 21,107 & 14,531 & 15,894 & 14,816 & 11,379 & 14,586 & 18,675 & 21,224 & 19,122 \\
\hline Poljska & 36,166 & 52,166 & 55,108 & 41,030 & 45,049 & 50,744 & 72,028 & 60,151 & 59,949 & 71,342 & 53,340 \\
\hline Rumunija & 8,466 & 15,083 & 19,393 & 12,657 & 16,458 & 21,060 & 19,438 & 20,489 & 19,153 & 19,181 & 15,143 \\
\hline Srbija & 26,309 & 25,189 & 23,634 & 18,726 & 16,854 & 16,110 & 17,175 & 14,866 & 13,103 & 11,545 & 10,331 \\
\hline Slovačka & 5,666 & 5,544 & 4,596 & 5,166 & 4,180 & 4,698 & 5,122 & 5,378 & 5,344 & 5,400 & 5,367 \\
\hline Slovenija & 22,313 & 23,398 & 19,386 & 13,207 & 13,613 & 14,275 & 16,525 & 14,212 & 12,389 & 12,265 & 13,817 \\
\hline
\end{tabular}

Izvor: https://www.ceicdata.com/en/indicator/market-capitalization--nominal-gdp (08.08.2019.)

Grafikon 4: Pokazatelj tržišne kapitalizacije BiH u usporedbi s tržištem Bugarske (\% nominalnog GDP -a)

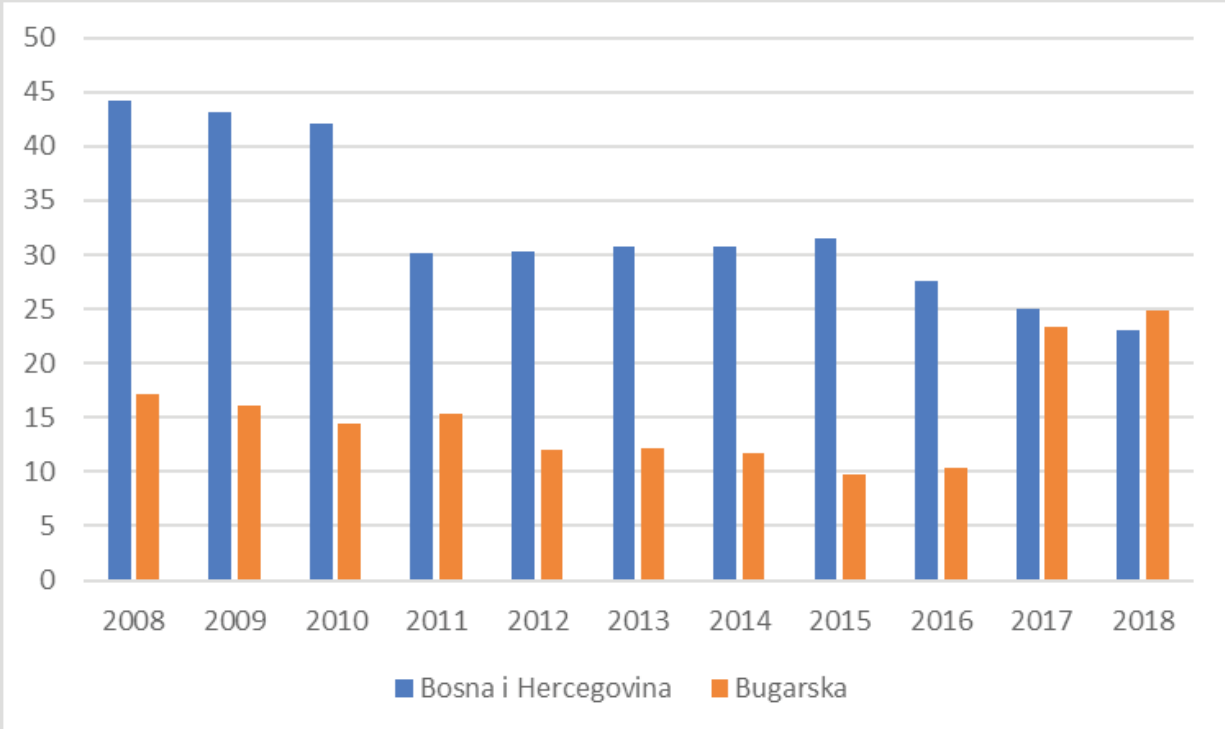

Izvor: https:/www.ceicdata.com/en/indicator/market-capitalization--nominal-gdp (08.08.2019.) 
Grafikon 5: Pokazatelj tržišne kapitalizacije BiH u usporedbi s tržištem Češke (\% nominalnog GDP -a)

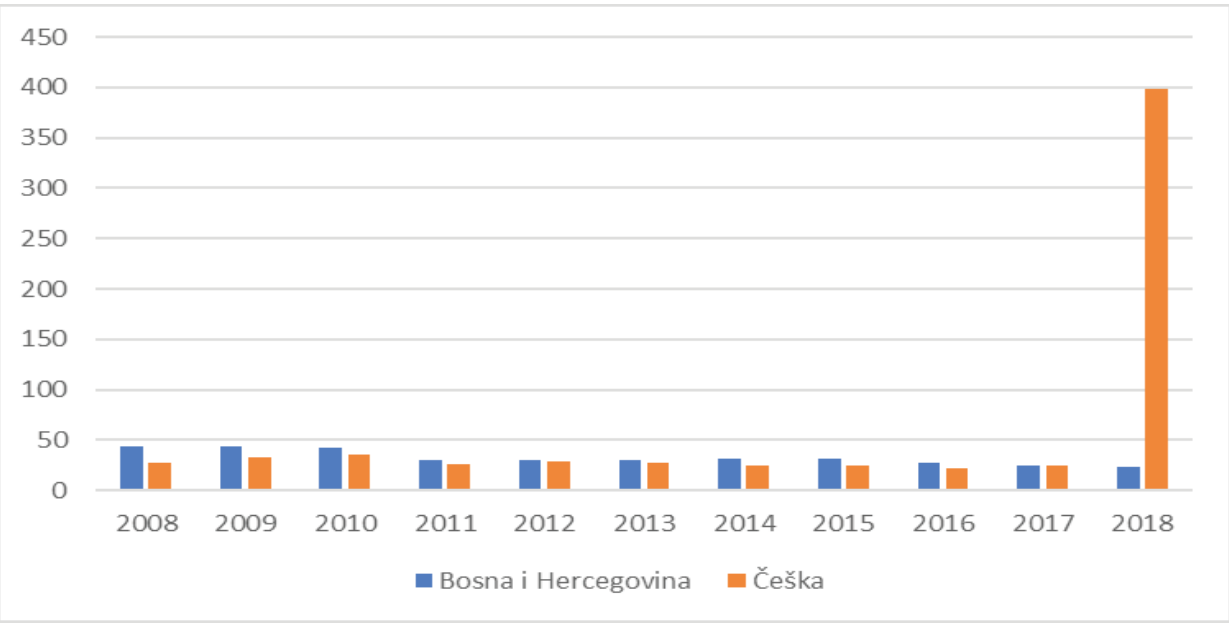

Izvor: https://www.ceicdata.com/en/indicator/market-capitalization--nominal-gdp (08.08.2019.)

Grafikon 6: Pokazatelj tržišne kapitalizacije BiH u usporedbi s tržištem Republike Hrvatske (\% nominalnog GDP -a)

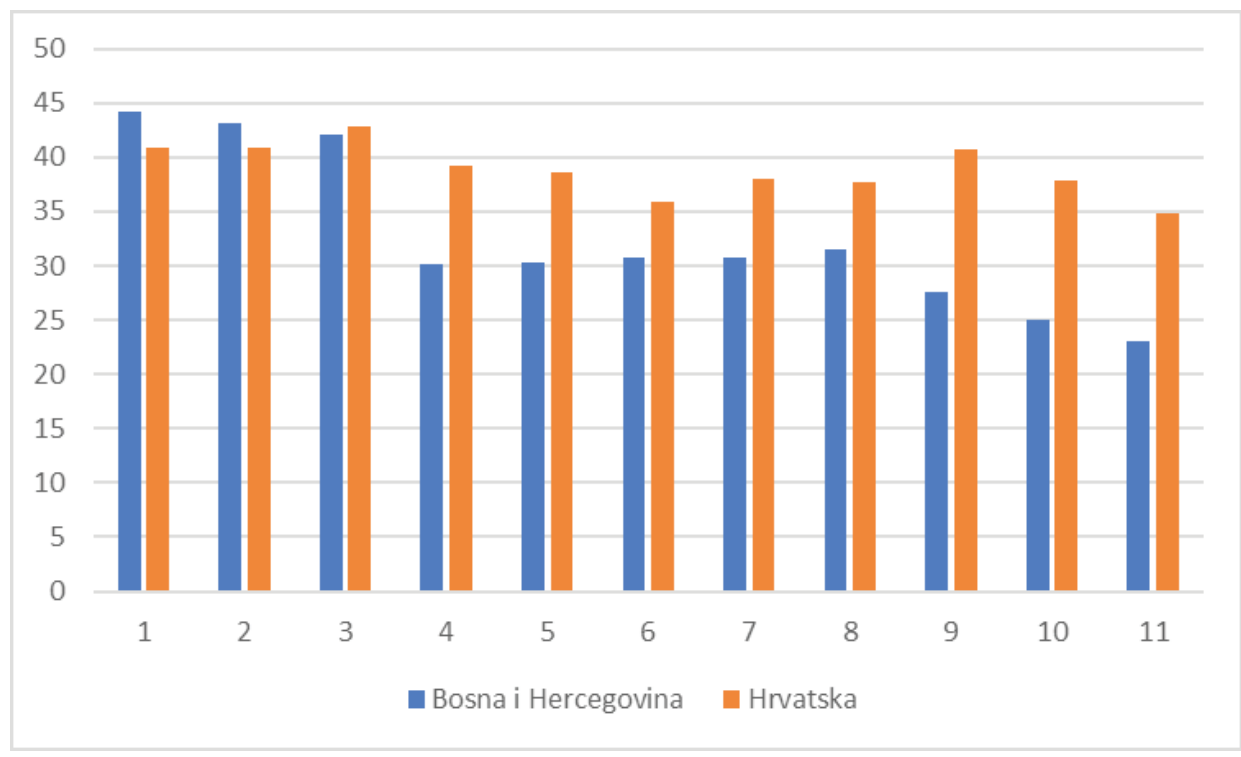

Izvor: https://www.ceicdata.com/en/indicator/market-capitalization--nominal-gdp (08.08.2019.) 
Grafikon 7: Pokazatelj tržišne kapitalizacije BiH u usporedbi s tržištem Republike Hrvatske (\% nominalnog GDP -a)

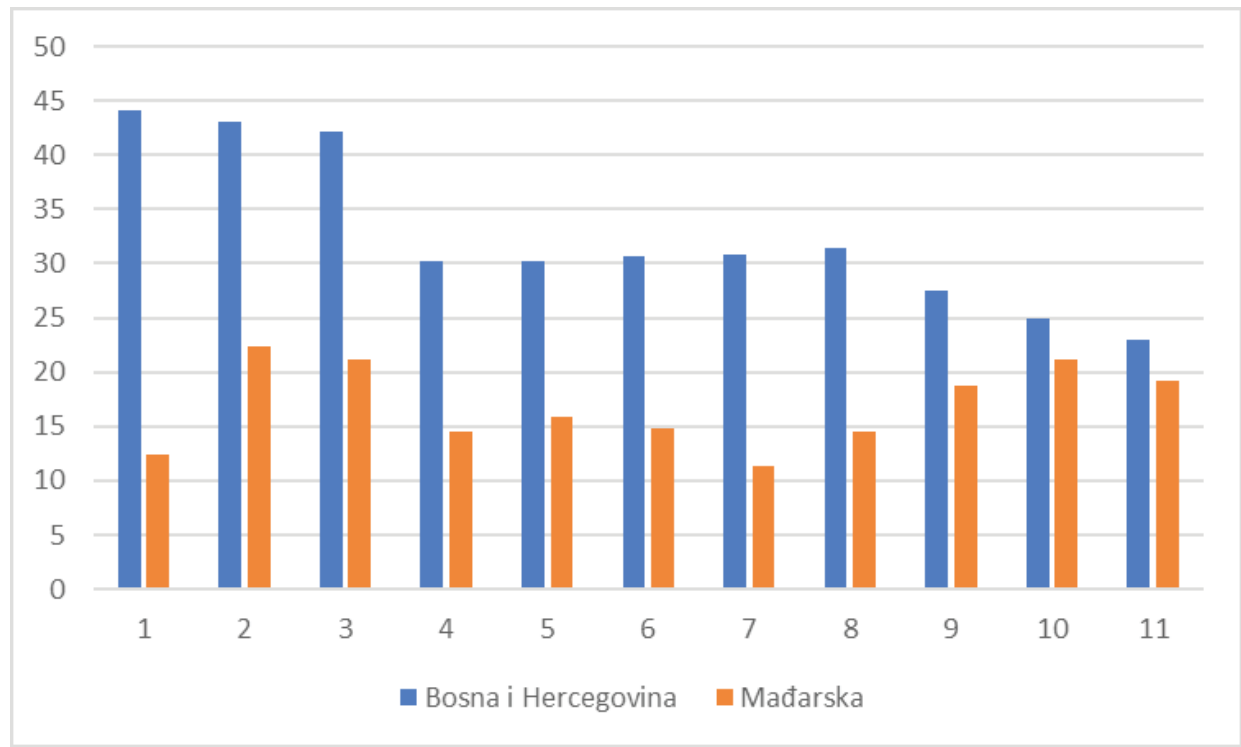

Izvor: https://www.ceicdata.com/en/indicator/market-capitalization--nominal-gdp (08.08.2019.)

Grafikon 8: Pokazatelj tržišne kapitalizacije BiH u usporedbi s tržištem Rumunjske (\% nominalnog GDP -a)

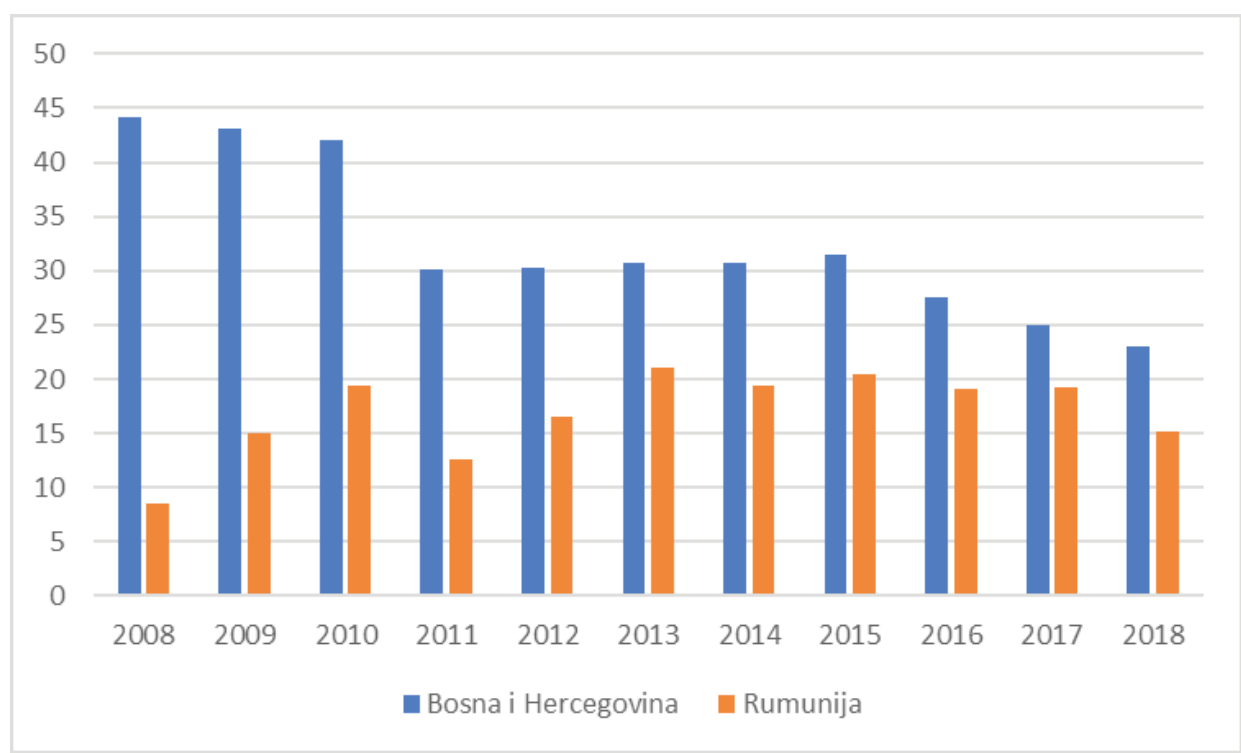

Izvor: https:/www.ceicdata.com/en/indicator/market-capitalization--nominal-gdp (08.08.2019.) 
Grafikon 9: Pokazatelj tržišne kapitalizacije BiH u usporedbi s tržištem Republike Srbije (\% nominalnog GDP -a)

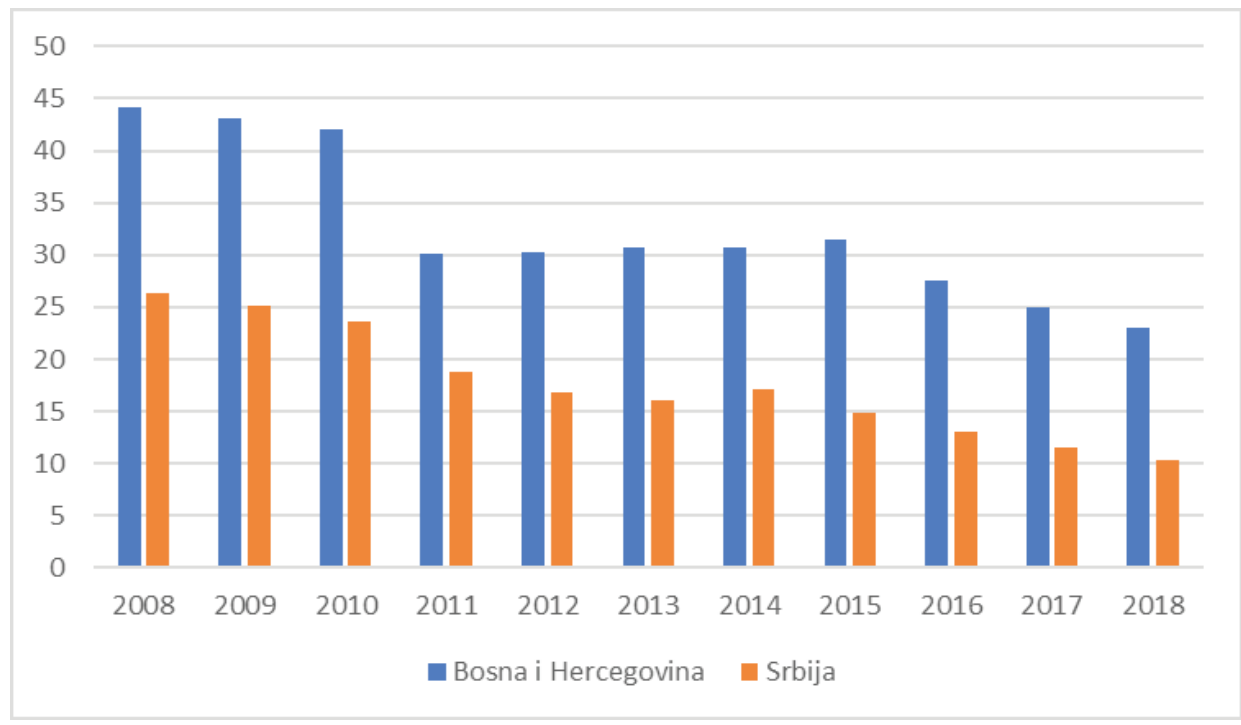

Izvor: https:/www.ceicdata.com/en/indicator/market-capitalization--nominal-gdp (08.08.2019.)

Grafikon 10: Pokazatelj tržišne kapitalizacije BiH u usporedbi s tržištem Slovačke (\% nominalnog GDP -a)

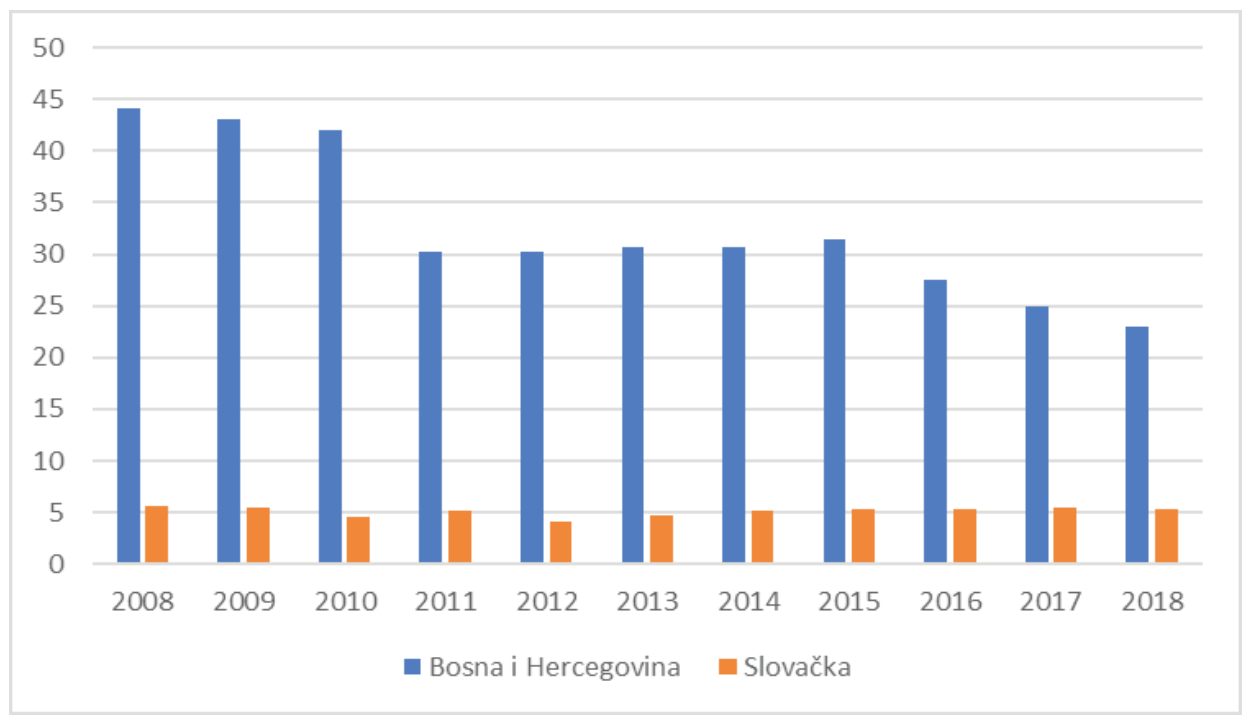

Izvor: https:/www.ceicdata.com/en/indicator/market-capitalization--nominal-gdp (08.08.2019.) 
Grafikon 11: Pokazatelj tržišne kapitalizacije BiH u usporedbi s tržištem Slovenije (\% nominalnog GDP -a)

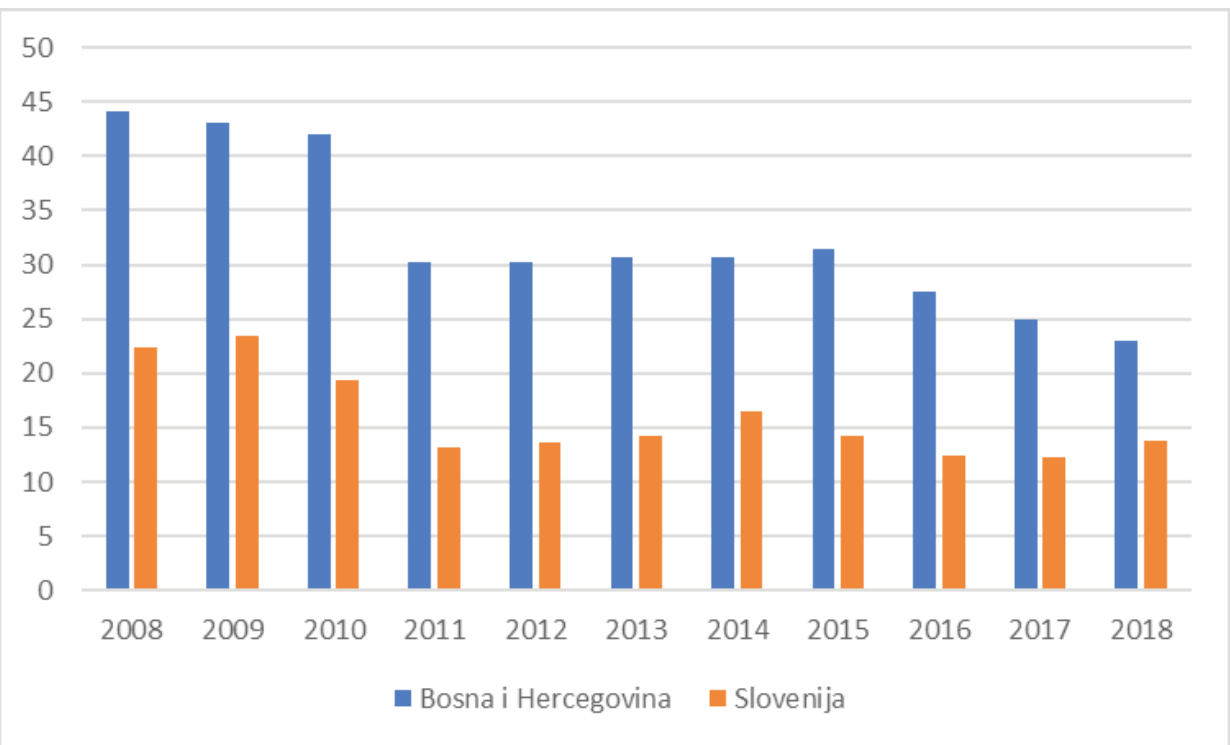

Izvor: https://www.ceicdata.com/en/indicator/market-capitalization--nominal-gdp (08.08.2019.)

Za razvijenost tržišta kapitala najčešći pokazatelj koji se uzima jeste odnos tržišne kapitalizacije i BDP-a. Odnos BDP-a i tržišne kapitalizacije kreće se u nerazvijenim zemljama ispod 5\%, manje razvijenim zemljama od 5 do $20 \%$, srednje razvijem zemljama između $20 \%$ i $40 \%$, više srednje razvijenim od $40 \%$ do $60 \%$, a najrazvijenijim tržištima prelazi 60\%.9 Analizirajući BiH od 2008. do 2010. godine tržište kapitala bilo je u usponu i nalazilo se u grupi više srednje razvijenih zemalja, da bi nakon 2010. godine pa sve do danas bliže bilo grupi manje razvijenim zemljama. Ako usporedimo odabrane zemlje srednjoistočne Europe, postotak razvijenosti jeste između 20\% i 40\%, kao i kod BiH. Od odabranih zemalja najbolji postotak razvijenosti pokazuje Poljska za koju se može reći da ide ka najrazvijenijim tržištima. Slabije pokazatelje od BiH imaju Bugarska, Mađarska, Rumunjska, Srbija, Slovačka te Slovenija.

9 Kumalić, I.(2013) „Razvijenost financijskog tržišta u Bosni i Hercegovini“ Časopis za ekonomiju i tržišne komunikacije, Fakultet poslovne ekonomije, Banja Luka, str. 68. 


\section{ZAKLJUČAK}

Prema izvješću Svjetske banke tržište kapitala BiH jeste malo i nerazvijeno, ali u budućnosti bi moglo imati veliku ulogu u razvoju gospodarstva zemlje. Podatci pokazuju da je $\mathrm{BiH}$ tržište kapitala nesigurno, plitko i nedovoljno razvijeno. Postotak tržišne kapitalizacije od $44 \%$ gdje je $\mathrm{BiH}$ tržište kapitala spadalo u grupu razvijenih tržišta, te cilj da se ta brojka dostigne nije se ostvario. Iz godine u godinu taj je postotak manji. Razlog tome može biti i sama organizacija tržišta, imajući na umu da su na tržištu prisutne dvije burze (SASE I BLBERZA). Sukladno tome postoje i dvije odvojene Komisije za vrijednosne papire te niz drugih akata kojima se regulira poslovanje dviju burzi zasebno. Na tržištu kapitala postoje dva sustava koja su međusobno nepovezana, te ne postoji jedinstvena institucija na koja bi burze moga regulirati kao jednu cjelinu.

Analizirajući rad burzi, vrijednosni papiri kojima se trguje su dionice, trezorski zapisi te obveznice. Kod razvijenih tržišta kapitala (svjetskim tržištima) svakodnevno se pojavljuju novi vrijednosni papiri , što znači da tržište kapitala BiH daleko zaostaje i ostaje siromašno vrijednosnicama kojima se trguje. Veći broj vrijednosnih papira nudi investitorima veći izbor investiramo i omogućava im povećanje njihovog portfelja. Ono što bi dodatno pomoglo tržištu kapitala $\mathrm{BiH}$ jesu strana ulaganja na dugi rok, čemu treba posvetiti više pažnje da bi se razvijalo financijsko tržište.

Razvijenost tržišta kapitala približno je na istom nivou kao kod Češke, Hrvatske i Poljske, što pokazuje tržišna kapitalizacija izmjerena u BDP - u. Karakteristike $\mathrm{BiH}$ tržišta kapitala su duple institucije, nefunkcionalnost, mali broj vrijednosnih papira kojima se može trgovati, nedovoljno razvijeno i siromašno. Da bi tržište kapitala BiH postalo razvijeno potrebno je izmijeniti zakonsku regulativu, integrirati dvije burze u jednu i uspostaviti jedinstvene institucije za upravljanje burzom.

\section{LITERATURA}

1. Jeremić, Z. (2012) „Finansijska tržišta i finansijski posrednici“, Univerzitet Singidunum, Beograd.

2. Juričić, Lj. (2010) „Financijska kriza i financijska politika “, Ekonomski pregled, Zagreb, Vol. 61, No. 5-6, 2010 str. 318.

3. Kumalić, I. (2013) „, Razvijenost financijskog tržišta u Bosni i Hercegovini“ Časopis za ekonomiju i tržišne komunikacije, Fakultet poslovne ekonomije, Banja Luka, 
4. Frenkel, R., Rapetti, M. (2009) „A developing country view of the current global crisis: what should not be forgotten and what should be done", Cambridge Journal of Economics, 2009., str. 687.

5. Gadžić, M. (2011) „Financijska tržišta i institucije“, Sveučilište u Mostaru, Mostar.

6. Grgić D., Kordić G. (2011) „Analogija krize zemlja s margine eurozone s krizom u Bosni i Hercegovini i Hrvatskoj “"Ekonomska misao i praksa, Sveučilište u Dubrovniku, No. 1, 2011, str. 212.-214.

7. Mishkin S. F., Easkin, G. S. (2005) „Financijska tržišta + institucije“, MATE, 2005. Zagreb.

8. https://www.cbbh.ba/?lang=hr

9. https://www.worldbank.org/

10. http://www.sase.ba/v1

11. https://www.blberza.com/Pages/Default.aspx

12. https://www.ceicdata.com/en 
Irena Planinić, BSc.

JP „Elektroprivreda HZ-HB“ d.d. - Mostar, B\&H

irena.planinic@ephzhb.ba

\title{
FINANCIAL MARKETS IN BOSNIA AND HERZEGOVINA TEN YEARS AFTER GLOBAL FINANCIAL CRISIS
}

Received: October 26, 2019

Accepted: December 15, 2019

Professional paper

\begin{abstract}
There is a strong correlation between economic development and the financial market. Economic development drives the growth of savings and thus the development of the financial market. An indicator of financial market development is market capitalization, measured as \% of nominal GDP. The paper analyzes the development of the capital market of Bosnia and Herzegovina with the transition countries of Central and Eastern Europe. Applying the analysis methods, the descriptive method, the quantitative and the comparative method, it seeks to establish that the capital market of Bosnia and Herzegovina, high risk, is underdeveloped and poor. Comparing it with the selected transition countries of Central and Eastern Europe, from 2008 to 2018, try to determine if there are major discrepancies in the development of the capital market.
\end{abstract}

Keywords: financial market, capital market;

JEL: E44 